\title{
Radon Gas as an Indicator for Air Quality Control in Buried Industrial Architecture: Rehabilitation of the Old Británica Warehouses in Alicante for a Tourist Site
}

\author{
Carlos Rizo-Maestre ${ }^{1, *}{ }^{\mathbb{C}}$, Víctor Echarri-Iribarren ${ }^{1}$, Raúl Prado-Govea ${ }^{1}$ and \\ Francisco Pujol-López ${ }^{2}$ (i) \\ 1 Department of Architectural Constructions, University of Alicante, 03690 Alicante, Spain \\ 2 Department of Computer Science and Technology, University of Alicante, 03690 Alicante, Spain \\ * Correspondence: carlosrm@ua.es
}

Received: 9 July 2019; Accepted: 14 August 2019; Published: 28 August 2019

\begin{abstract}
The infrastructure of the Británica warehouses in Alicante is a very important industrial architectural element in the history of Spain, although it is unknown to almost all of the inhabitants of the city. The former fuel refinery is located in the Serra Grossa Mountains and served much of the country until 1966. This research is based on the plans of the city of Alicante to convert a historical element, the Británica warehouses, into a unique tourist site. Currently, the network of storage domes in this facility, which has an approximate footprint of $20,000 \mathrm{~m}^{2}$ and domes approximately $20 \mathrm{~m}$ high, is in a state of neglect, and there are neighborhood initiatives for its rehabilitation to become a cultural or tourist site. Therefore, it is necessary to take into account the quality of the indoor air. Radon gas is analyzed as a control element for future refurbishment of the facility. Alicante is a nongranite area and therefore is not very susceptible to generation of radon gas indoors, but the conditions of a buried and poorly ventilated space make the site appropriate for analysis. Most scientific agencies in the field of medicine and health, including the World Health Organization, consider radon gas to be very harmful to humans. This element in its gaseous state is radioactive and is present in almost all the land in which the buildings are implanted, with granitic type soils presenting higher levels of radon gas. Nongranitic soils have traditionally been considered to have low radon levels. The city of Alicante, where the installation is located, is a nongranitic area and therefore is not very susceptible to generating radon gas in buildings, but the conditions of buried and poorly ventilated places make the site appropriate for analysis to support air quality control and decision-making.
\end{abstract}

Keywords: healthy architecture; construction materials; environment; radon; underground building; heritage building

\section{Introduction}

The majority of scientific agencies in the field of medicine and health, including the World Health Organization, consider radon gas to be very harmful to humans. This element in its gaseous state is radioactive, and higher levels of radon gas are present in almost all granitic soils in which buildings are located. Nongranitic soils have traditionally been considered to have low radon levels.

This research is based on the plans of the city of Alicante to convert a historical element, the Británica warehouses (Figure 1), into a singular tourist site therefore, the quality of the interior air has to be taken into account. Radon gas is analyzed as a control element for future rehabilitation.

Alicante is in a nongranitic area that is not very susceptible to generation of radon gas in buildings, but the conditions of a buried and poorly ventilated space make the site appropriate for analysis. 


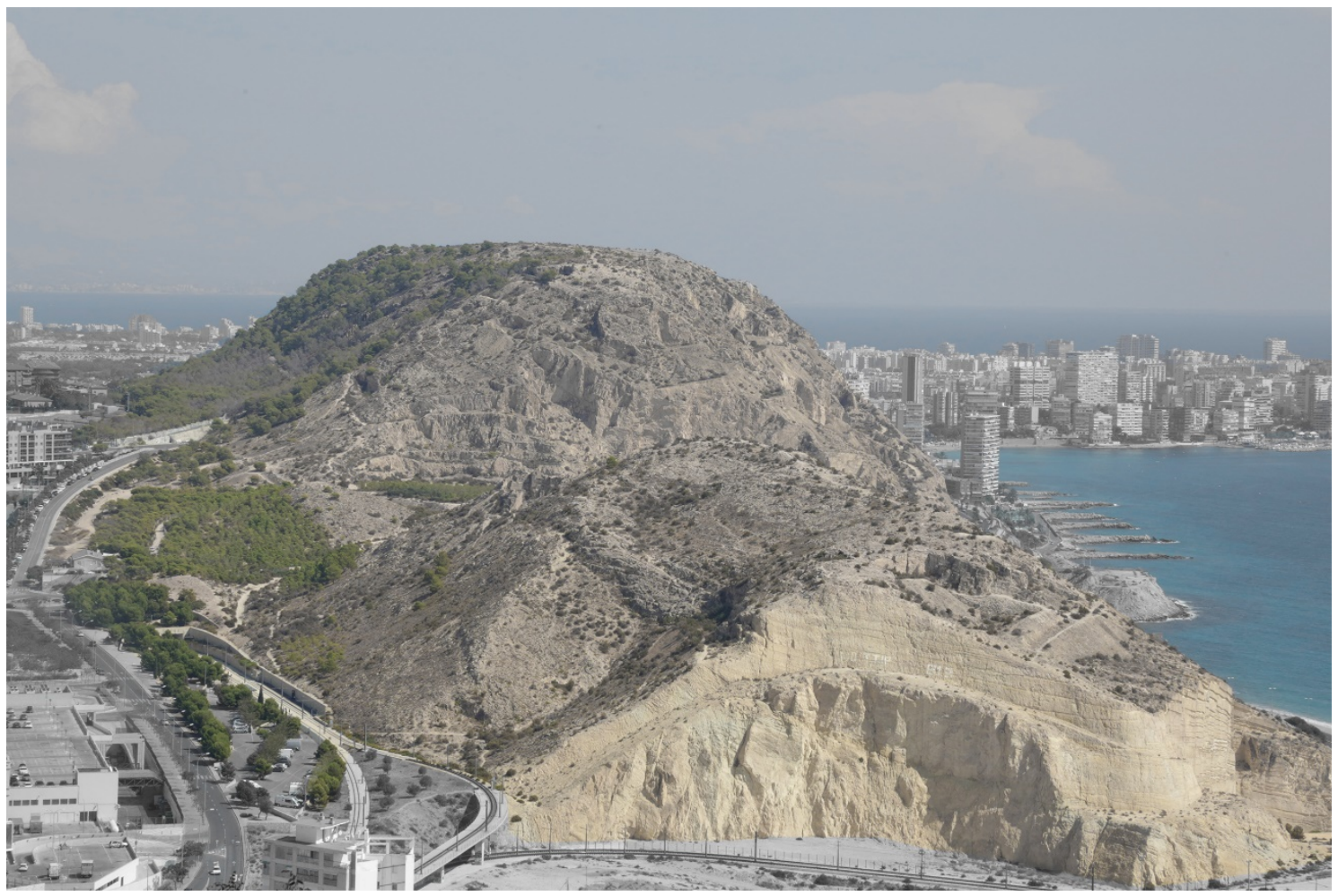

Figure 1. Image of the Serra Grossa from the Castle of Santa Bárbara on Monte Benacantil (own source).

\subsection{Radon Gas and Health}

Radon is a chemical element belonging to the group of noble gases. It is found mainly in the subsoil. The uranium in the soil disintegrates and produces radon, which remains in the soil. When decomposed, it is released to the surface in the form of a gas. In its gaseous form, it is colorless, odorless and tasteless and therefore undetectable [1,2].

Radon gas occurs as a result of the decay of the uranium contained in rocks [3]. Radon emanates from the ground and is concentrated mostly in enclosed spaces [4], so it is highly recommended that homes and workplaces are properly ventilated [5].

Three-quarters of the radioactivity in the environment comes from natural elements [6]. Radon is the major source of natural radioactivity [7], and the public health problem generated by its concentration both inside buildings and in drinking water means that it must be considered for evaluation [8].

Radon decays due to so-called ionizing radiation because, when it enters matter, it usually pulls electrons out of the surrounding atoms by a process known as ionization [9]. If the matter is biological tissue with a high water content, the ionization of the water molecules can give rise to so-called free radicals with a high chemical activity [10], sufficient to alter important molecules that form part of the tissues of living beings [11]. These alterations may include chemical changes in DNA, the basic organic molecule that forms part of the cells that make up our bodies [12]. These changes may lead to the appearance of biological effects, including abnormal cell development [13]. These alterations may be more or less severe depending on the dose of radiation received [14]. The main effect of the presence of radon in the human environment is the risk of lung cancer [15]. This radioactive gaseous element is present in almost all construction materials and in the ground on which buildings are constructed [16].

Different radon-measuring devices are available. Some are active, require electricity and allow continuous recording of radon gas concentrations and fluctuations during the measurement period [17]. Others are passive and do not require electrical current to operate in the sampling environment [18].

Electret ion chambers (CIE) have been used to carry out this research. CIE are passive devices that function as integrating detectors to measure the average concentration of radon gas during the 
measurement period. The electret functions both as an electric field generator and as a sensor in the ionic chamber. The radon gas enters the chamber by diffusion through an inlet equipped with a filter without allowing the rest of the elements produced during the disintegration process to pass [19]. The radiation emitted by the radon and its disintegration products formed inside the chamber ionize the air inside the chamber by reducing the detector surface voltage [20]. Subsequently, a calibration factor relates this voltage drop to the radon concentration existing in the space and time studied.

The most important source of radon in isolated buildings or ground floors is the radon present in the ground. The radon concentration in the soil is generally between 10 and $50 \mathrm{~Bq} / \mathrm{kg}$, although it can reach much higher values. The average value is approximately $40 \mathrm{~Bq} / \mathrm{kg}$. The amount of radon entering a building's interior from the soil depends mainly on the concentration of radium-226 in the subsoil and the permeability of the subsoil.

Predictive maps of radon content are available in most countries, based mostly on the igneous compositions of the ground [21]. For example, Sweden has developed maps based on the measurement of the geogenic potential of radon, which indicates the level of risk by area estimated from the concentration of radon in the ground at a depth of 1 meter [22]. Likewise, the usefulness of methods based on other variables, such as the concentration of radium-226 in the soil or the equivalent of uranium (eU), has been proven. In the case of France, for example, the national map has been drawn up on the basis of geological maps and the average uranium content of each geological unit [23]. The German map [24] and the Czech map [25] have also been elaborated using the geogenic potential of radon. All radon gas predictive maps consider granitic soils to be the highest risk in terms of concentrations [26] and consider clay soils to have a low presence of radon gas. In Spain, the Technical Building Code (CTE), as of February 2018, did not regulate the maximum dose of radon allowed in a building and how to contain it [27].

The Spanish Mediterranean coast, where the city of Alicante is located, is mainly clay [28]. In the urban center of the city are the two mountains compared in the study: Monte Benacantil and Serra Grossa. Therefore, they can be considered to have the same igneous composition.

The ventilation of building interiors is essential to define their air quality because the greater the air renewal rate [29], the fewer stale particles remain in the environment [30]. Therefore, the presence of radon gas is used to analyze whether ventilation is adequate inside railway tunnels, i.e., whether the area where the extraction machines are located (Monte Benacantil) has better ventilation than the area where it is excavated in the rough (Serra Grossa) [31].

\subsection{Radon Gas Regulations in Spain}

In Spain, the National Institute for Occupational Safety and Hygiene, under the Ministry of Labor and Social Affairs, has published two related Technical Protection Standards [32], from which most of the paragraphs in this section have been extracted. The NTPs are guides to good practice and specifications, although they are not obligatory unless they are included in a regulatory provision in force, and they follow the recommendations of the European public body in charge of coordinating nuclear energy research programs, the European Nuclear Energy Community, or EURATOM.

According to NTP 533 "Radon and its effects on health", experimental studies carried out on animals that have been irradiated, as well as those carried out on people who, for various reasons, have been subjected to high doses of radiation, have shown that ionizing radiation constitutes a carcinogenic agent. The appearance of cancer usually occurs several years after receiving irradiation, being a late effect, probabilistic or stochastic. The probability evidently increases with the dose.

The first works citing the carcinogenicity of radon in animals (rats and monkeys) exposed by inhalation to concentrations of $27.8 \times 10^{6} \mathrm{~Bq} / \mathrm{m}^{3}$ were carried out in 1943 . In subsequent acute toxicity studies with the same species for periods of three to seven weeks and with exposure to radon inhalation concentrations between $18.5-740 \times 10^{6} \mathrm{~Bq} / \mathrm{m}^{3}$, the effects found for whole-body irradiation were pulmonary congestion and, frequently, paralysis of the hind limbs. X-rays revealed hyperactivity in the skin, lungs, and adrenal glands [31]. 
The first epidemiological studies on which the association between exposure to radon and lung cancer is based were carried out in workers in uranium mines, demonstrating an incidence of lung cancer 50 times higher than the average of the unexposed population in the mining population of several countries [33]. Due to insufficient ventilation, the high concentration of uranium (and as a consequence, of radium-226) produced a high concentration of radon and its byproducts, which when inhaled generated lung cancer. Although cancer was initially associated only with inhalation of solid matter, the importance of gas in the induction of the disease was later noted. The latency period of the disease was set at 20 years.

In the absence of sufficient data, estimates of the risk associated with domestic radon exposure were initially based on extrapolation of the results obtained for miners. This extrapolation had a series of limitations, among which the following stand out:

- The absence of data concerning women and children, who obviously did not work in the mines.

- Uncertainties in the effect on health of the dose rate.

- Lack of data on smoking habits in most studies.

- Inadequate control of other confounding variables (such as exposure to gamma radiation or suspended aerosols).

Therefore, to specifically assess the risk of cancer associated with radon exposure in housing, a number of epidemiological studies of varying scope were undertaken from the 1980s onwards. They have shown that the risk associated with household exposures is higher than that predicted by extrapolation from the cohort of miners. According to studies conducted in Europe [34], China [35] and North America [36], an increase of $100 \mathrm{~Bq} / \mathrm{m}^{3}$ in the mean radon concentration in a household leads to a $10 \%$ increase in the likelihood of lung cancer.

In short, radon has been considered carcinogenic by the World Health Organization (WHO) since 1998, according to the International Agency for Research on Cancer (IARC) and the U.S. Environmental Protection Agency (EPA), which classify it as a Group 1 and Group A carcinogen, respectively. The main adverse effect of inhaling radon and its breakdown products is the risk of lung cancer.

Radon, as a gas, is not significantly retained in the respiratory tract. However, $90 \%$ of its descendants may be attached to aerosol particles present in the air, which, depending on their size, may be retained at different levels of the respiratory system. The smallest, the respirable fraction, will reach the most sensitive areas of bronchial and pulmonary tissue, depositing there, along with the remaining $10 \%$ of the disintegration products. The deposition of these particles generates a source of emission of high-density $\alpha$ particles, so that a part of this tissue receives a high exposure, increasing the possibility of developing a carcinogenic process. The dose received in the lung by beta radiation $(\beta)$ or gamma radiation $(\gamma)$ is negligible compared to that due to alpha particles $(\alpha)$.

In Spain, the most valuable source of environmental radiological information is the Natural Gamma Radiation Map (Marna) [37]. The Marna evaluates the rate of exposure to terrestrial gamma radiation of natural origin referenced to one meter above ground level, which has an excellent correlation with the content of radium-226, which is the precursor isotope of radon. Because the currently available network of radon measurements in homes is not dense enough, the Marna offers a good alternative for developing a radon exposure predictive map.

\section{The Británica Warehouses as a Future Tourist Site in the City of Alicante}

Inside the Serra Grossa is one of the most important engineering works of the 20th century, unknown to almost all the inhabitants of the city: the storage domes of an old oil refinery that in the past was initially owned by the state and then by the private company Campsa (Figure 2). This infrastructure served a large part of the country until 1966, when a more modern refinery was inaugurated in the port of Alicante. At present, it is in a state of abandonment, and there are neighborhood initiatives for its rehabilitation and for it to become a cultural or tourist site. Therefore, it will house people, and it is vitally important to conduct a study of indoor air quality. 


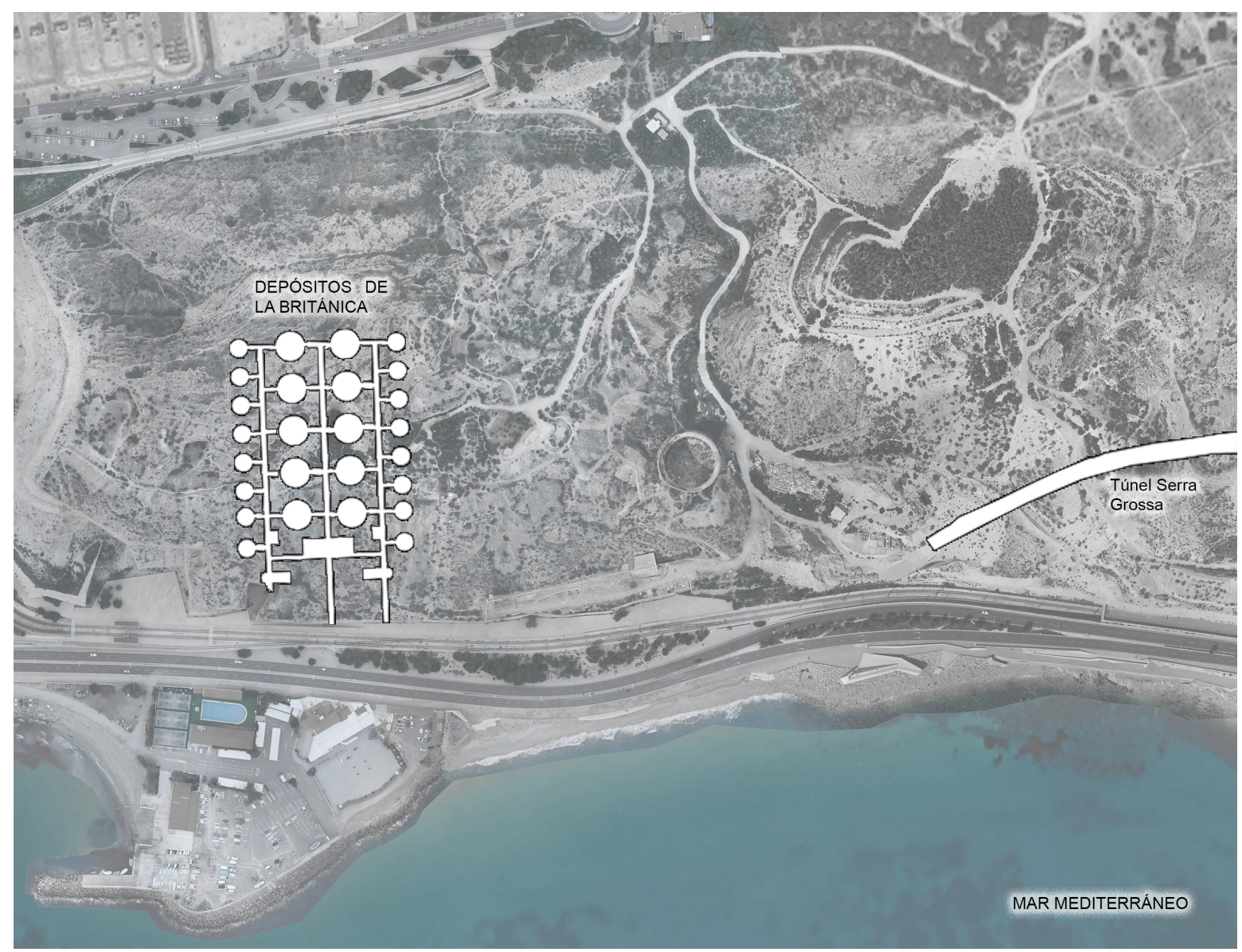

Figure 2. Image of the location of the Británica warehouses on the Serra Grossa from a drone flight (own source).

This industrial facility was used for refining oil and its derivatives, from storage to distribution. The installation included surface and other underground constructions excavated in the rock of the Serra Grossa. This complex was internally connected with galleries and tunnels at different heights that connected the interior rooms with the exterior rooms (Figure 3).

Today, despite decades of deterioration, you can still see part of the complex, especially the parts that remain buried in the mountain. In its interior remain part of the elements of the old factory; wagons, rails and electric cables are between dirt and complete abandonment.

The study of indoor air quality within this complex with radon gas as an indicator is presented not only because of its interesting architectural morphology built on the mountain but also because of its importance in the history of the city and the residents' lack of knowledge about the site. 

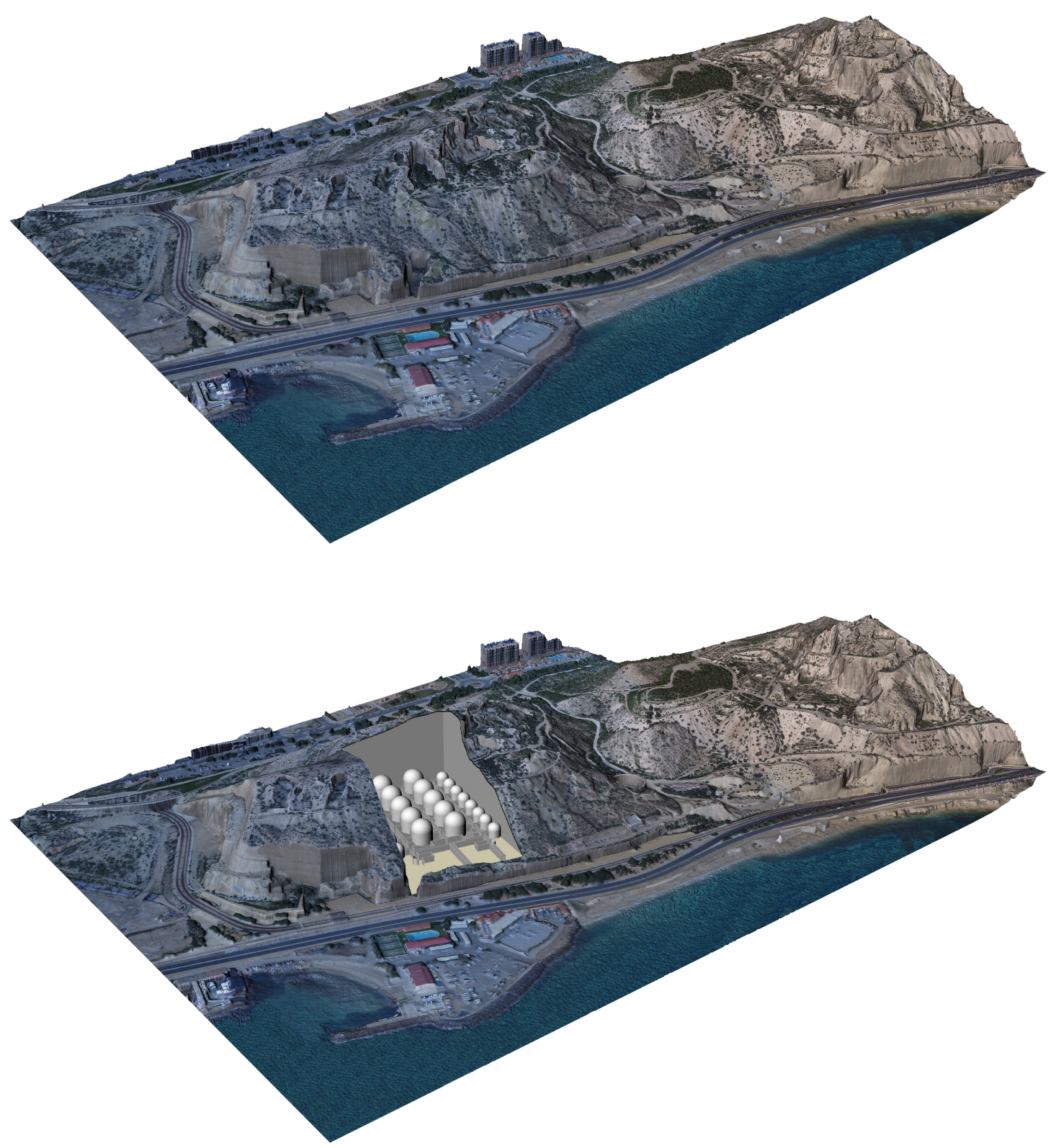

Figure 3. 3D image made with drone photogrammetry of the location of the Británica warehouses (own source).

\subsection{History of the Place}

The city of Alicante is very important at a strategic military level due to its port and Mediterranean location. In the past, the province had two oil refineries, one of them located in Benalúa (from "Industrias Fourcade y Provot") and the other in the southern area of Serra Grossa on the site of an old metallurgical company called "La Británica", from which the Británica warehouse complex inherited its name. The Británica factory received the crude oil from its own pier, Santa Ana, which later became known as Pichón's Shot. The first company to exploit the refinery was Deutsch y Cía in 1875; later, it was used by the company El León.

The refinery grew as the country required its services due to the increase in population. At the beginning of the 20th century, it supplied $55 \%$ of the Spanish market to be used for, among other uses, public lighting and both civil and military vehicles. In 1903, an enormous delimiting wall was erected 
for the factory, as seen in the photos of the time (Figure 4). In 1915, the refinery was linked to the railroad. In 1929, the pier was destroyed by a storm and was not rebuilt to link to the factory.

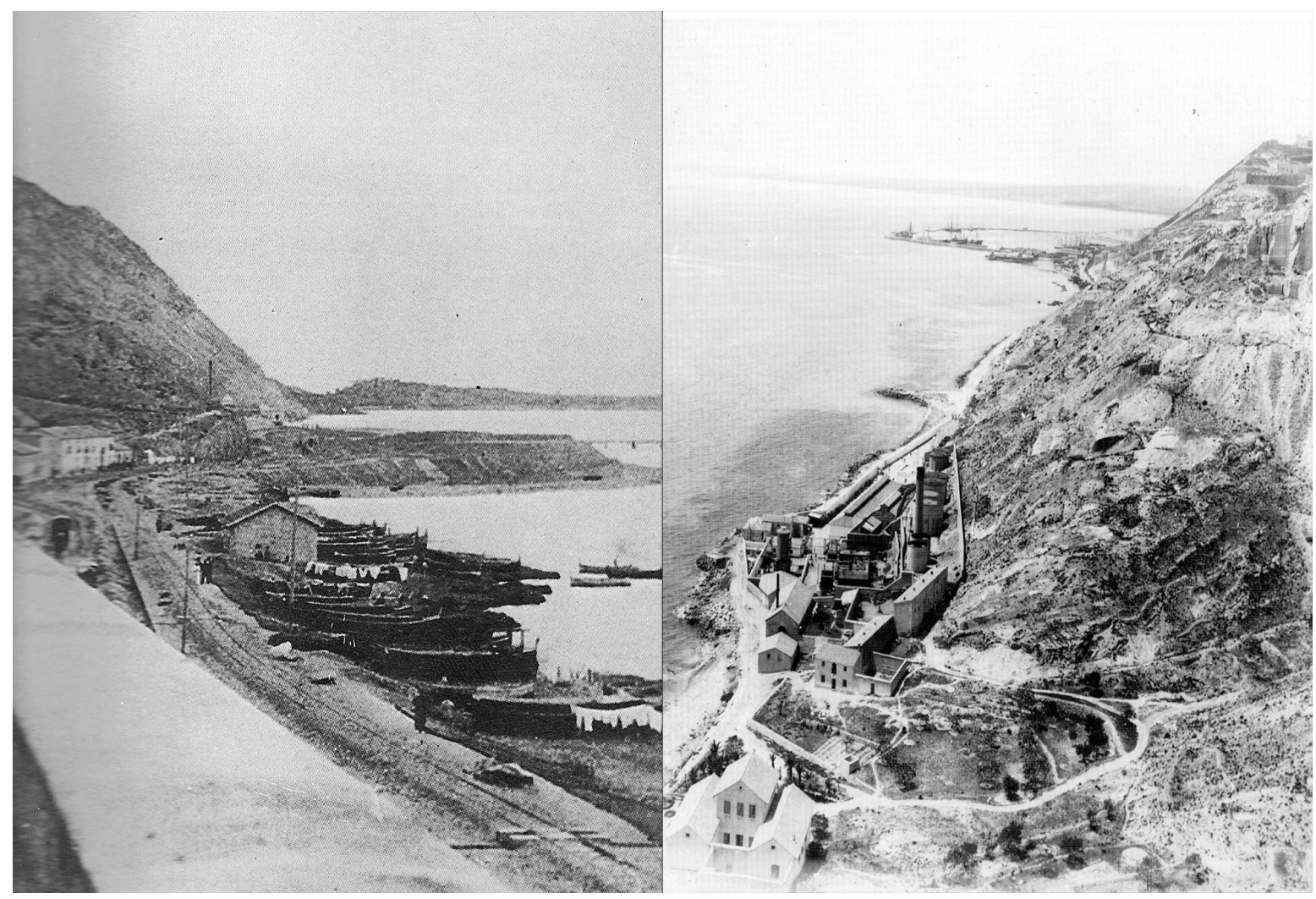

Figure 4. Left: Image of the Raval Roig and the boats of the Postiguet in the foreground. The factory is in the background, with the jetty and the chimney. Image from the beginning of the 20th century. Right: Image of the factory in 1909 (source: Alicante Vivo).

In 1929, the facility was acquired by the national company Campsa, which had a monopoly on the country's oil. At that time, the factory covered approximately $72,000 \mathrm{~m}^{2}$. The facility was modernized due to the demand for fuel. With the existing political situation on the verge of warfare, the need for crude oil was growing, and the location of the depots was a concern because it was an area vulnerable to bombardment and easy combustion.

In 1932, an expansion and remodeling project was presented to be able to face the demand for increasing the capacity of the tanks. In 1937, the project for Campsa's underground factory was presented. Excavation continued until the 1950s, and the interior was reinforced with shotcrete to hold the vaults. This process of remodeling the factory was carried out to protect one of the most important assets during the period of wars of the time.

When the Spanish Civil War ended in 1939, the underground factory began to be excavated, the exterior installations were modified, new tanks with more capacity were added, and the employees' homes were removed (Figure 5). 


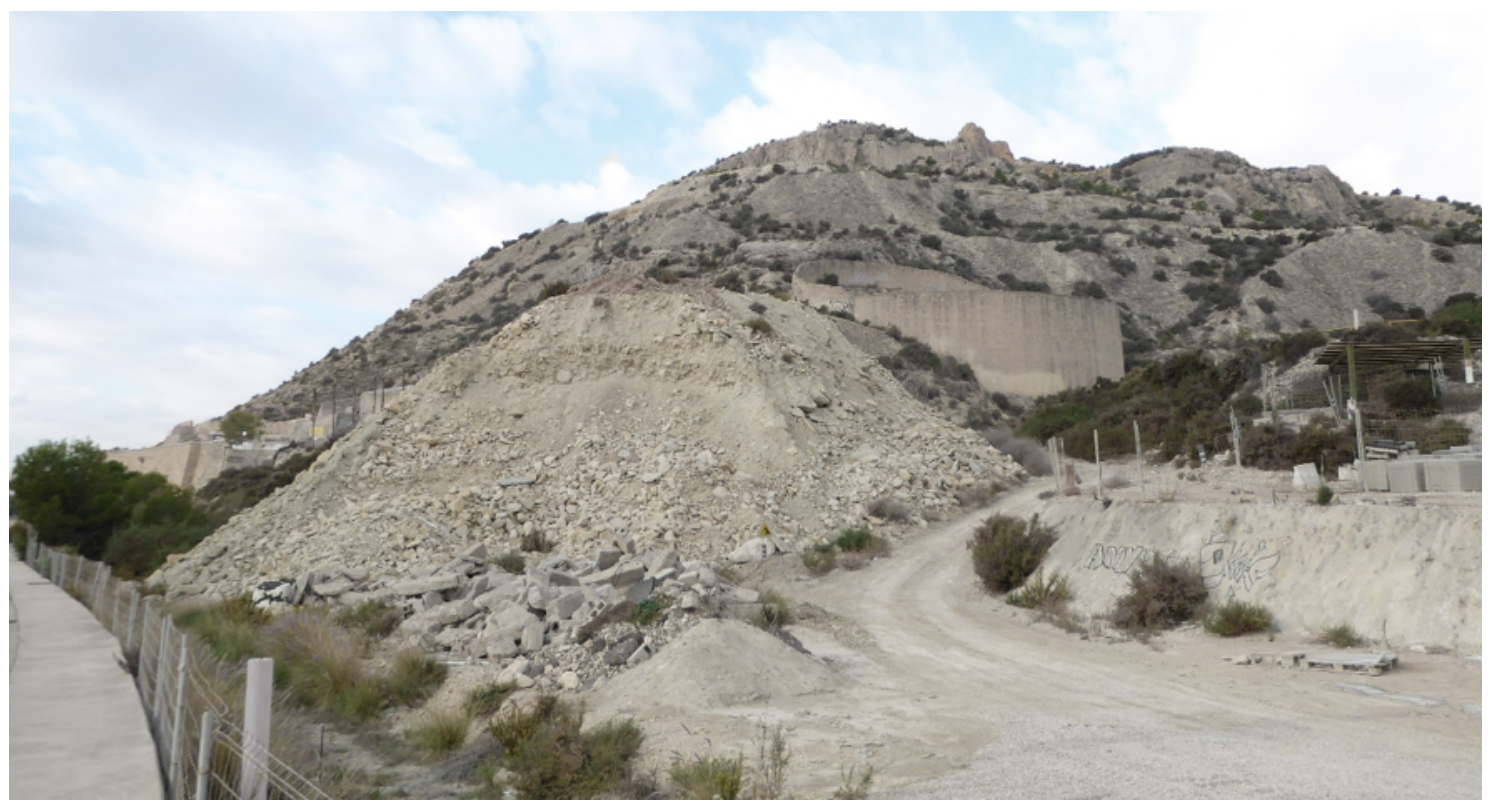

Figure 5. Image of the external tank of the refinery that is still conserved (own source).

The facilities were used uninterruptedly until they were abandoned in 1966, when Campsa moved its operations to the Port of Alicante, in the area now known as Panoramis; they remained there until they were relocated in 1979 to the outskirts of the city (Figure 6).

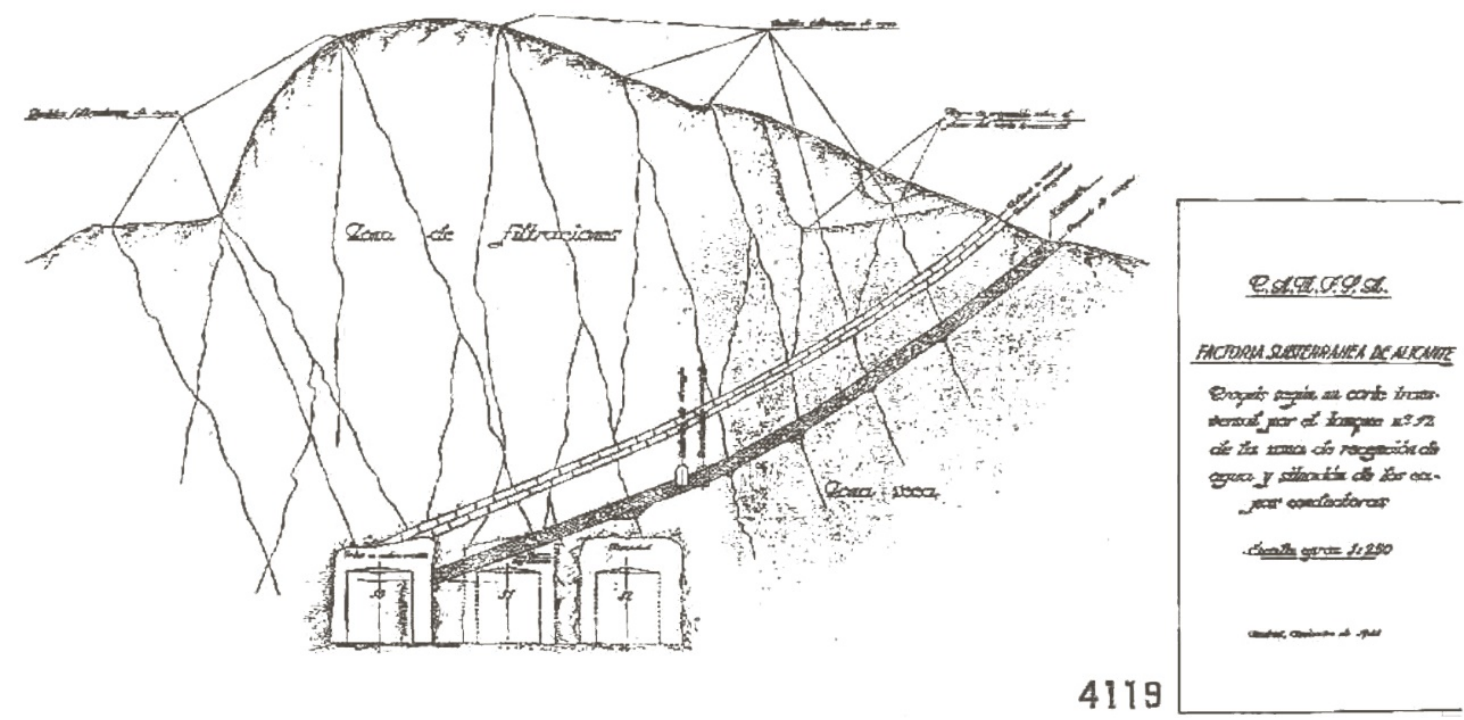

Figure 6. Image of the section of the vaults of the original project of the Británica warehouses (source: original project, AMA files).

With the end of its use, all the tools that had served in the factory premises were removed for different reasons. According to testimonies at the time, the cutting of one of the fuel tanks caused a fire that lasted several days, and the smoke produced left the walls of the vaults completely black, as can be seen today.

\subsection{Architectural Description of the Complex}

In addition to the underground volumes that make up the complex today, there are a few elements that were once part of this important industrial factory in the city. Currently, it is abandoned, and due to its dimensions and historical route, it can be considered within the framing of industrial archaeology. 
The enclosure consisted of three main galleries and seven secondary galleries, linked in a grid pattern that housed large concrete vaults on their sides in which metal tanks were installed to store the crude oil. The main vaults were approximately $20 \mathrm{~m}$ high and $18 \mathrm{~m}$ in diameter. The communication galleries had average dimensions of $3 \mathrm{~m}$ by $2 \mathrm{~m}$ in height and a length of approximately $160 \mathrm{~m}$. The layout can be seen in Figure 7, showing 10 main and 16 secondary vaults. The total footprint of the subterranean facility is located in a rectangle of 170 by $120 \mathrm{~m}$.

The main entrance to the complex was the high central gallery, where maintenance and repair work was carried out. The fuel tanks were filled by means of large pipelines that came to the surface and connected with the external plants for distillation and refining of crude oil.

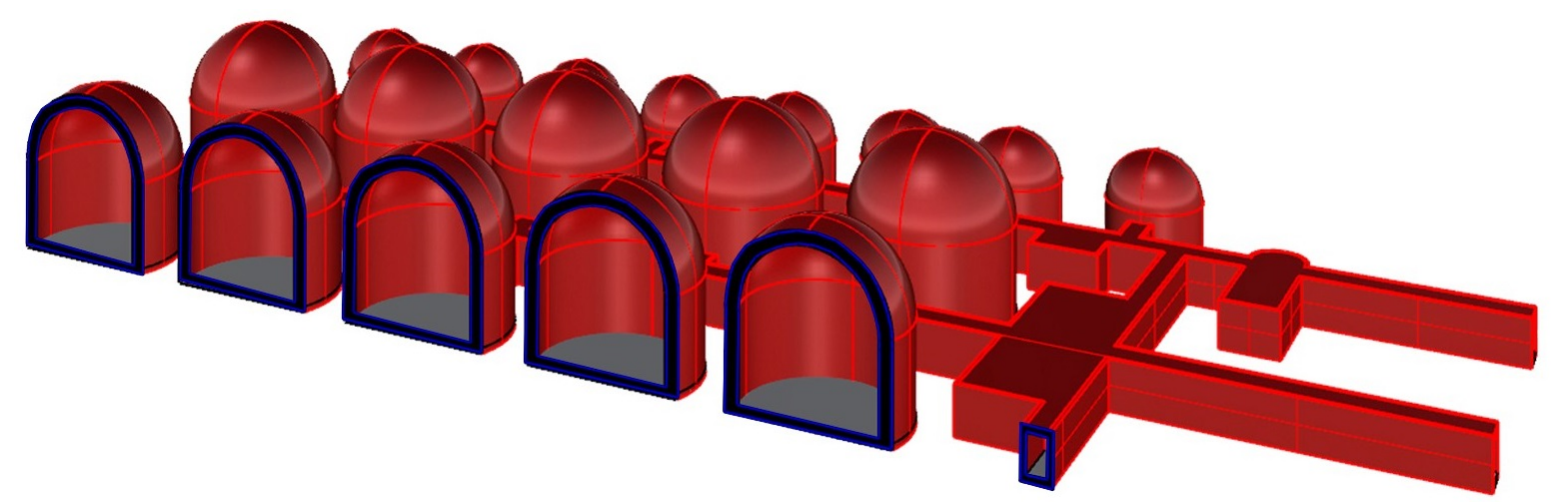

Figure 7. 3D reconstruction of the tanks (own source).

On the lower level, there were different outbuildings, such as warehouses, workshops, offices, garages, warehouses and even workers' homes. All of this area was demolished and at the moment serves as the Sangueta stop of the Metropolitan Transport of Alicante.

On the next level was the large exterior tank, which is still partially standing, and the chimney, which can be seen in the photos of the period. There were also old exterior gabled naves with masonry walls.

\section{Building Materials in Británica Warehouses: The Current Complex and Future Proposals for Use}

The Británica warehouses were a work of considerable technical difficulty for the time as they were underground tanks holding the fuel reserves for part of the country and were located inside the mountain, which is now called the quarry. This area was the origin of San Julian's stone, which was highly valued for ancient and important buildings in the city, such as the city hall and the Cathedral of St. Nicholas.

The underground installation consists of a set of circular naves with domes excavated from the rock and reinforced with reinforced concrete connected by long corridors. All this construction was calculated to be able to contain the weight of the mountain and, in case of enemy attack, to keep the fuel well protected. During tank inspections, in addition to radon analyses, samples of different construction materials were extracted for further analysis.

As described, the complex has been in disuse since 1966, and no work has been carried out to reconvert or clean up the site. The refinery has been used for shooting films but has not had a subsequent use due to the low level of conservation that it has had during the last 50 years. Various proposals have been made to rehabilitate the complex, including for a leisure and cultural park that would take advantage of the underground enclosures and high domes as an auditorium area.

The municipal Special Archaeological Protection Plan of Alicante has collected the proposals but did not grant any type of protection. A report by the Directorate General of Heritage of the Department of Culture of the Valencian Community recommended that the facilities be declared a "Property of 
Local Relevance". Figure 8 shows one of the entrances to the complex from the Sangueta stop that was finally built.

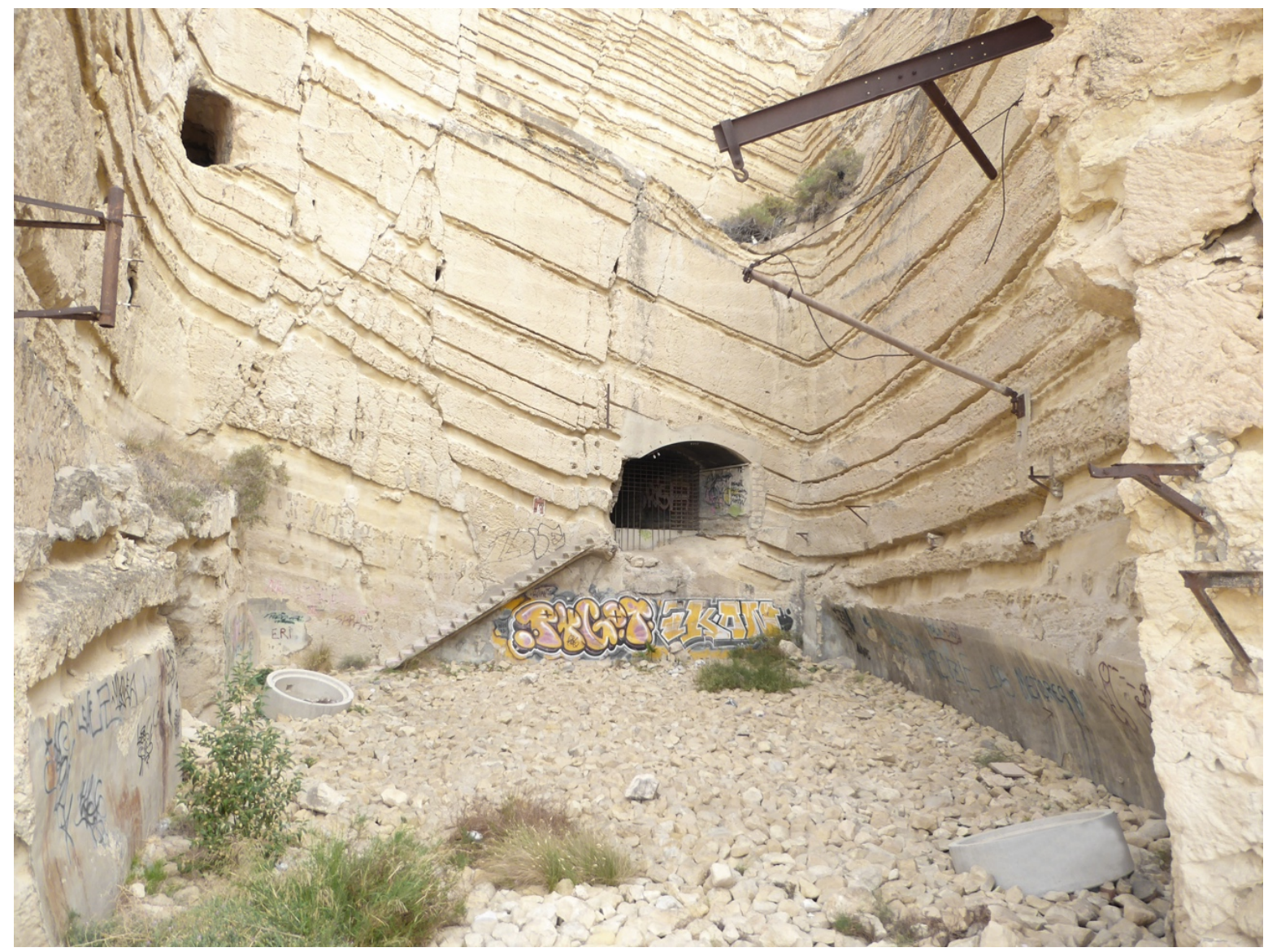

Figure 8. Image of the southern entrance to the complex, which was used as access to make the measurements taken from the stop of the TRAM de la Sangueta. It is trellised and in a deteriorated state such as the rest of the accesses (own source).

During the study of the layout for the new metro line crossing the Serra Grossa to the north, consideration was given to the possibility of cutting through the factory as part of the excavation of the tunnel, which would have meant the total loss of the site. This idea was discarded by the Conselleria de Infraestructuras y Transportes, which makes later rehabilitation possible to enable viable approaches of recovery similar to the aforementioned ones.

\section{Study of the Quality of the Air in the Británica Warehouses}

The study carried out inside the old fuel tanks of the Británica warehouses lasted two days, beginning on 7 September 2016. The entrance to the site was made through the south door, which is currently partially closed with damaged grilles that do not impede passage. Through this door, access was gained to carry out the study. In the mountain, there are other hidden entrances that connect with the large galleries, but they are closed and have not been explored during the work in the complex.

The measurement areas of the study in the old Británica deposits were as follows, as shown in Figure 9: 
1. Zone 1

2. Zone 2

3. Zone 3

4. Zone 4

5. Zone 5

6. Zone 6

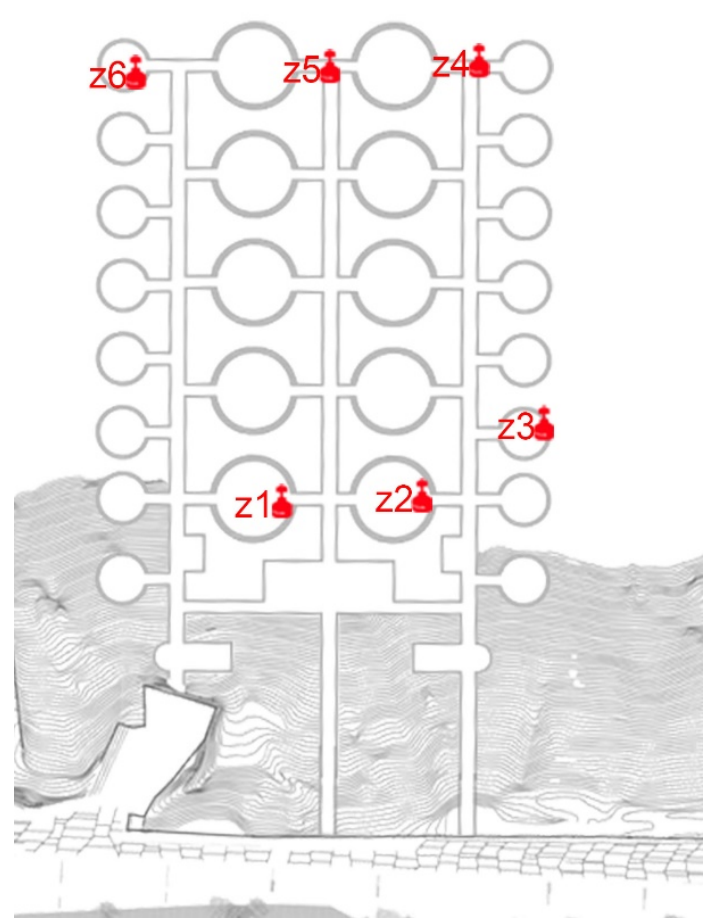

Figure 9. Plant image of the placement of the measuring devices inside the old tanks (own source).

The design of this work allows the communication of all of the rooms. The only ventilation comes from the main entrances and some elements that emerge at the top of the mountain that in the past served the factory to treat the fuel, so the air renewal is virtually null.

This old factory is very interesting for the study of the amount of radon gas because of its location in the Serra Grossa and the type of construction. In addition, due to its activity, it played a tremendous role in the supply of petroleum products for the whole country, and its underground structure is the product of engineering more than 60 years ago, having endured although the mountain rests on it, with domes close to $20 \mathrm{~m}$ high.

\subsection{Radon Measuring System}

The radon gas measuring system used in the study was a short chamber and short electret of the Eperm System for two days (Figure 10). The complex morphology of the site means that all the rooms studied have similar conditions of low ventilation. 


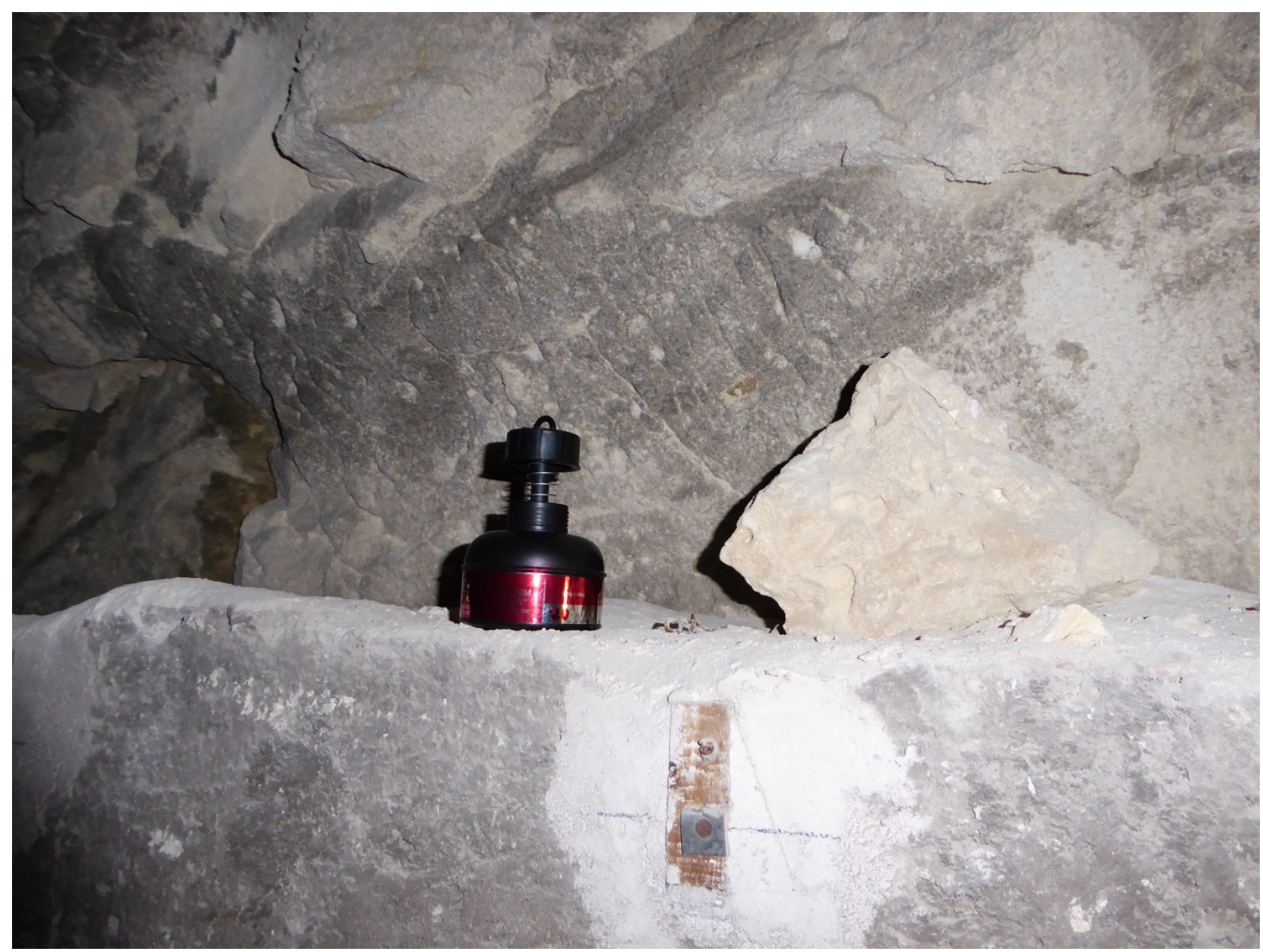

Figure 10. Image of the data collection phase inside the tanks (own source).

\subsection{Climatology during the Study}

The average temperatures recorded in the city of Alicante during the time of the study were between $23{ }^{\circ} \mathrm{C}$ and $32{ }^{\circ} \mathrm{C}$, and there was no precipitation, although that would not have considerably impacted the underground tanks.

The temperature inside the tanks is similar to that recorded inside the tunnel that passes a few meters into Serra Grossa itself, with average values close to $17^{\circ} \mathrm{C}$.

\subsection{Results Obtained in the Study}

The equipment introduced into the tanks was placed for two days in different rooms with a unique combination of short-short camera-electret. The results obtained in the six previously chosen zones are shown in Figure 11. 


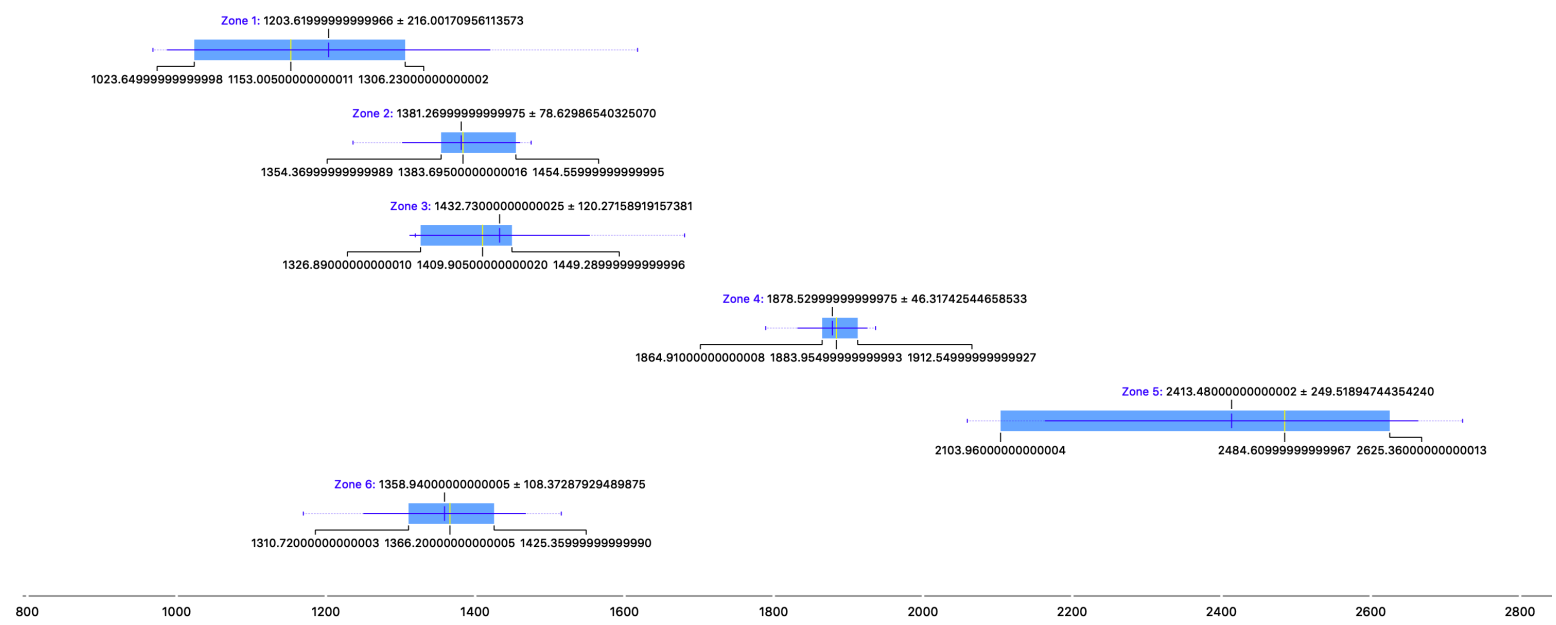

Figure 11. Measurements carried out in the Británica tanks (own source).

\section{Discussion of Results}

The representation of the radon gas results in the environment of the Británica tanks obtained using the combination of short chamber and short electret is provided in a comparative table that shows the different measurement areas and the obtained average environmental concentrations of the gas in $\mathrm{Bq} / \mathrm{m}^{3}$. Table 1 and Figure 12 show the dispersion of the results in each of the zones.

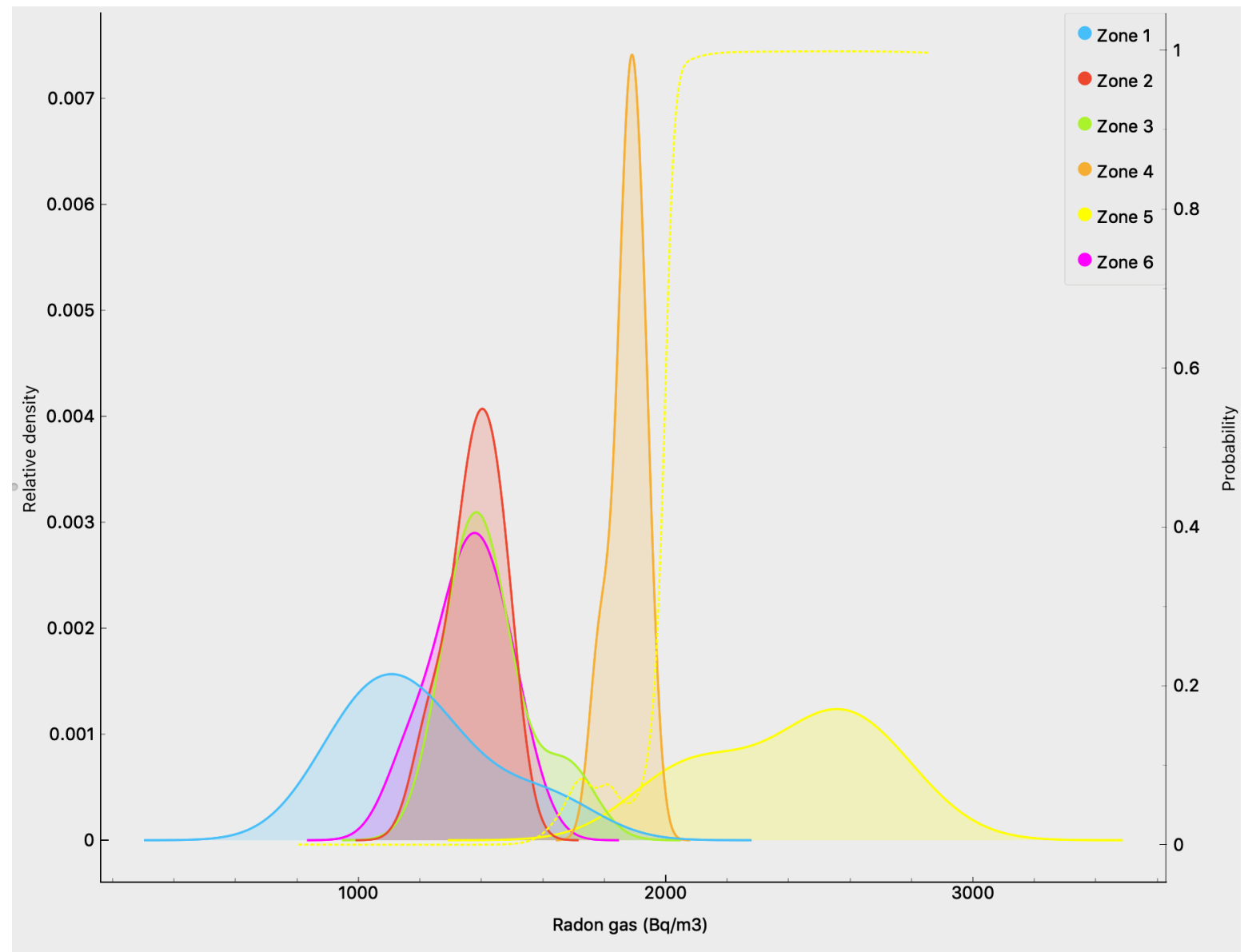

Figure 12. Chart showing the dispersion of the results obtained in the six measurement zones (own source). 
Table 1. Summary of the measurements carried out in the Británica tanks (own source).

\begin{tabular}{cccc}
\hline Zone & Place & Number of Samples & Average Gas Concentration Radon $\left(\mathbf{B q} / \mathbf{m}^{\mathbf{3}}\right)$ \\
\hline Zone 1 & Dome 1 & 6 & 1203,62 \\
Zone 2 & Dome 2 & 6 & 1381,27 \\
Zone 3 & Dome 3 & 6 & 1432,73 \\
Zone 4 & End of Corridor 1 & 6 & 1878,53 \\
Zone 5 & Aisle 2 & 6 & 2413,48 \\
Zone 6 & Dome 4 & 6 & 1358,94 \\
\hline
\end{tabular}

The results obtained in the installation show a high average amount of radon gas inside, which is explained by the limited air movement that occurs and the contact with the ground. In the different measurements, the radon gas accumulation obtained varied between 1203.62 and $2413.48 \mathrm{~Bq} / \mathrm{m}^{3}$, quadrupling the threshold of $300 \mathrm{~Bq} / \mathrm{m}^{3}$ in the most favorable case. Thus, this study has established a value from which it is necessary to take corrective ventilation measures. A heat map of the results is shown in Figure 13.

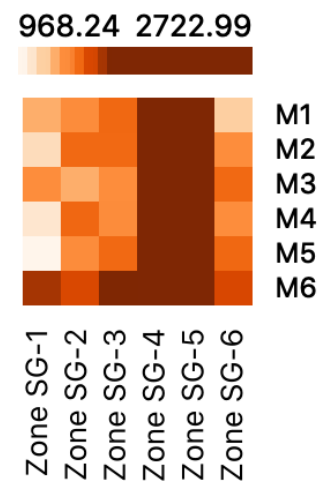

Figure 13. Heat map of the results obtained (own source).

\section{Conclusions}

The infrastructure of the Británica warehouses of Alicante is a very important industrial architectural element in the history of Spain, although it is unknown to almost all the inhabitants of the city. The former fuel refinery is located in the Serra Grossa and served much of the country until 1966.

As an element for the future accommodation of people, it is necessary to carry out an air quality study with radon gas as an indicator. The results obtained in the installation show a high average amount of radon gas inside, which is explained by the limited air movement and its contact with the ground. The values in the eleven measurement zones varied between 1203.62 and $2413.48 \mathrm{~Bq} / \mathrm{m}^{3}$, quadrupling the threshold of $300 \mathrm{~Bq} / \mathrm{m}^{3}$ in the most favorable case, and establishing values for which corrective ventilation measures must be taken.

The old Británica warehouses exhibit radon values much higher than those estimated for constructions in Alicante, if we consider the Marna map, where the area of the Levante is considered low risk. When this area is rehabilitated as recently proposed, the observation of high amounts of radon gas inside must be addressed and solutions adopted. These must be oriented to better renew the interior air by means of mechanical processes to avoid making more openings in the mountain that would distort the landscape and weaken the structure. It is for this reason that the current conditions should not be considered suitable for accommodating people until remodeling projects that include adequate ventilation of the installation have been carried out.

Author Contributions: The work presented here was developed in collaboration among all the authors. All of the authors have contributed to, seen and approved the manuscript.

Acknowledgments: The authors of this paper thank the University of Alicante for the grant that allowed part of this research. 
Conflicts of Interest: The authors declare no conflicts of interest.

\section{References}

1. Leccese, F.; Salvadori, G.; Barlit, M. Ventilated flat roofs: A simplified model to assess their hygrothermal behaviour. J. Build. Eng. 2019, 22, 12-21. [CrossRef]

2. Leccese, F.; Rocca, M.; Salvadori, G. Fast estimation of speech transmission index using the reverberation time: Comparison between predictive equations for educational rooms of different sizes. Appl. Acoust. 2018, 140, 143-149. [CrossRef]

3. Lavi, N.; Steiner, V.; Alfassi, Z.B. Measurement of radon emanation in construction materials. Radiat. Meas. 2009, 44, 396-400. [CrossRef]

4. Maestre, C.R.; Yepes, S.C. Detection and importance of the presence of Radon Gas in buildings. Int. J. Eng. Tech. Res. (IJETR) 2016, 4, 67-70.

5. Cuvier, A.; Panza, F.; Pourcelot, L.; Foissard, B.; Cagnat, X.; Prunier, J.; van Beek, P.; Souhaut, M.; Roux, G.L. Uranium decay daughters from isolated mines: Accumulation and sources. J. Environ. Radioact. 2015, 149, 110-120. [CrossRef]

6. Szabó, K.Z.; Jordan, G.; Ákos Horváth.; Szabó, C. Mapping the geogenic radon potential: Methodology and spatial analysis for central Hungary. J. Environ. Radioact. 2014, 129, 107-120. [CrossRef]

7. Collignan, B.; Powaga, E. Impact of ventilation systems and energy savings in a building on the mechanisms governing the indoor radon activity concentration. J. Environ. Radioact. 2017. [CrossRef]

8. Miguel, M.G.T.S.; Matarranz, J.L.M.; de Mingo, R.G.; Cadierno, J.P.G.; Mahou, E.S. El Mapa Predictivo de Exposición al Radón en España; Editor Consejo de Seguridad Nuclear. Available online: https:/ / www.foronuclear.org/es/publicaciones-y-documentacion/recomendaciones-bibliograficas/120471el-mapa-predictivo-de-exposicion-al-radon-en-espana (accessed on 6 August 2019).

9. United Nations Scientific Committee on the Effects of Atomic Radiation. Sources and Effects of Ionizing Radiation: United Nations Scientific Committee on the Effects of Atomic Radiation: UNSCEAR 2000 Report to the General Assembly, with Scientific Annexes; United Nations: New York, NY, USA, 2000.

10. Cristobo, J.J.J.L. Medición de la Concentración de Gas 222Rn en el Interior de Edificios; USC Departamento de Física de las Partículas. Available online: http://fpsalmon.usc.es/Diplomas/DEA_JJLLerena.pdf (accessed on 6 August 2019).

11. Boerma, M.; Sridharan, V.; Mao, X.W.; Nelson, G.A.; Cheema, A.K.; Koturbash, I.; Singh, S.P.; Tackett, A.J.; Hauer-Jensen, M. Effects of ionizing radiation on the heart. Mutat. Res. Rev. Mutat. Res. 2016, 770, 319-327. [CrossRef]

12. Bhattacharya, S.; Asaithamby, A. Ionizing radiation and heart risks. Semin. Cell Dev. Biol. 2016, 58, 14-25. [CrossRef]

13. Ravanat, J.L.; Douki, T. UV and ionizing radiations induced DNA damage, differences and similarities. Radiat. Phys. Chem. 2016, 128, 92-102. [CrossRef]

14. Amber, I.; O'Donovan, T.S. Natural convection induced by the absorption of solar radiation: A review. Renew. Sustain. Energy Rev. 2018, 82, 3526-3545. [CrossRef]

15. Maestre, C.R.; Yepes, S.C. Radon Gas. Hazardous element for human life really found in the environment. In Proceedings of the 2nd International Conference on Green Materials and Environmental Engineering, Phuket, Thailand, 20-21 December 2015; Atlantis Press: Paris, France, 2015; pp. 60-62.

16. De Seguridad Nuclear, C. Dosis de Radiación; Editor Consejo de Seguridad Nuclear. Available online: https: //www.csn.es/documents/10182/914805/Dosis\%20de\%20radiaci\%C3\%B3n (accessed on 6 August 2019).

17. Barbosa-Lorenzo, R.; Ruano-Ravina, A.; Caramés, S.C.; Barros-Dios, J.M. Radón residencial y cáncer de pulmón. Un estudio ecológico en Galicia. Med. Clin. 2015, 144, 304-308. [CrossRef]

18. Nastro, V.; Carnì, D.L.; Vitale, A.; Lamonaca, F.; Vasile, M. Passive and active methods for Radon pollution measurements in historical heritage buildings. Measurement 2018, 114, 526-533. [CrossRef]

19. Li, P.; Zhang, R.; Gu, M.; Zheng, G. Uptake of the natural radioactive gas radon by an epiphytic plant. Sci. Total Environ. 2018, 612, 436-441. [CrossRef]

20. Zeeb, H. International Radon Project. Survey On Radon Guidelines, Programmes and Activities; WHO HSE/PHE/RAD. Available online: https:/ / www.who.int/ionizing_radiation/env/radon/IRP_Survey_on_ Radon.pdf (accessed on 6 August 2019). 
21. Duval, J.S. Use of Aerial Gamma-Ray Data to Estimate Relative Amounts of Radon in Soil Gas; U.S. Geological Survey: Reston, VA, USA, 1971; pp. 155-161.

22. Amgarou, K. Long-Term Measurements of Indoor Radon and Its Progeny in the Presence of Thoron Using Nuclear Track Detectors a Novel Approach; Universitat Autònoma de Barcelona: Barcelona, Spain, 2003.

23. Cambeses, A.; Garcia-Casco, A.; Scarrow, J.H.; Montero, P.; Pérez-Valera, L.A.; Bea, F. Mineralogical evidence for lamproite magma mixing and storage at mantle depths: Socovos fault lamproites, SE Spain. Lithos 2016, 266-267, 182-201. [CrossRef]

24. Tanner, A.B. Methods of Characterization of Ground for Assessment of Indoor Radon Potential at a Site. Available online: https://books.google.co.th/books?id=Vc1RAQAAMAAJ\&pg=PA1\&lpg=PA1\& $\mathrm{dq}=$ Methods + of + Characterization + of + Ground + for + Assessment+of+Indoor+Radon+Potential+at+a+Site; +1991\&source=bl\&ots=h8OPIDzW2n\&sig=ACfU3U0hIJZJ5xQFanQOkFt0B0BmJXwAw\&hl=en\&sa=X\& ved=2ahUKEwjRzZOOrKXkAhWBP48KHVw9D2UQ6AEwAHoECAYQAQ\#v=onepage\&q=Methods\% 20of\%20Characterization\%20of\%20Ground\%20for\%20Assessment $\% 20$ of\%20Indoor\%20Radon\%20Potential\% 20at\%20a\%20Site\%3B\%201991\&f=false (accessed on 6 August 2019).

25. Ielsch, G.; Cushing, M.E.; Combes, P.; Cuney, M. Mapping of the geogenic radon potential in France to improve radon risk management: methodology and first application to region Bourgogne. J. Environ. Radioact. 2010, 101, 813-20. [CrossRef]

26. Kemski, J.; Siehl, A.; Stegemann, R.; Valdivia-Manchego, M. Mapping the geogenic radon potential in Germany. Sci. Total Environ. 2001, 272, 217-30. [CrossRef]

27. Neznal, M.; Matolín, M.; Barnet, I.; Mikšová, J. The New Method for Assessing the Radon Risk of Building Sites; Prace Ceskeho Geologickeho Ustavu; Czech Geological Survey: Brno-střed-Staré Brno, Czechia, 2004; pp. 7-47.

28. Buttafuoco, G.; Tallarico, A.; Falcone, G. Mapping soil gas radon concentration: A comparative study of geostatistical methods. Environ. Monit. Assess. 2007, 131, 135-151. [CrossRef]

29. Olaya, M.; Borja, F. El Código Técnico de la Edificación en España (CTE) Medidas Correctoras Destinadas a Frenar la Entrada de Radón en los Edificios. Investigación de Campo como Experiencia Piloto en España. Available online: https: / / docplayer.es / 22067449-El-codigo-tecnico-de-la-edificacion-en-espana-cte-medidascorrectoras-destinadas-a-frenar-la-entrada-de-radon-en-los-edificios.html (accessed on 6 August 2019).

30. Cepedal, A.; Fuertes-Fuente, M.; Martín-Izard, A.; García-Nieto, J.; Boiron, M.C. An intrusion-related gold deposit (IRGD) in the NW of Spain, the Linares deposit: Igneous rocks, veins and related alterations, ore features and fluids involved. J. Geochem. Explor. 2013, 124, 101-126. [CrossRef]

31. Maestre, C.R.; Iribarren, V.E. The radon gas in underground buildings in clay soils. The plaza balmis shelter as a paradigm. Int. J. Environ. Res. Public Health 2018, 15, 1004. [CrossRef]

32. Maestre, C.R.; Iribarren, V.E. The importance of checking indoor air quality in underground historic buildings intended for tourist use. Sustainability 2019, 11, 689. [CrossRef]

33. Krewski, D.; Lubin, J.H.; Zielinski, J.M.; Alavanja, M.; Catalan, V.S.; Field, R.W.; Klotz, J.B.; Letourneau, E.G.; Lynch, C.F.; Lyon, J.I.; et al. Residential radon and risk of lung cancer: A combined analysis of 7 North American case-control studies. Epidemiology 2005, 16, 137-145. [CrossRef] [PubMed]

34. 440, N. Radón en Ambientes Interiores. Available online: http://insht.es/InshtWeb/Contenidos/ Documentacion/FichasTecnicas/NTP/Ficheros/401a500/ntp_440.pdf (accessed on 6 August 2019).

35. 533, N. El radón y sus Efectos Sobre la Salud. Available online: https:/ / www.insst.es/InshtWeb/Contenidos / Documentacion/FichasTecnicas/NTP/Ficheros/501a600/ntp_533.pdf (accessed on 6 August 2019).

36. Darby, S.; Hill, D.; Auvinen, A.; Barros-Dios, J.M.; Baysson, H.; Bochicchio, F.; Deo, H.; Falk, R.; Forastiere, F.; Hakama, M.; et al. Radon in homes and risk of lung cancer: collaborative analysis of individual data from 13 European case-control studies. BMJ 2005, 330, 223. [CrossRef] [PubMed]

37. Mahou, E.S.; Ángel Fernández Amigot, J.; Espasa, A.B.; Bonito, M.C.M.; del Pozo, J.M.; del Busto, J.M.L. Proyecto Marna (Mapa de Radiación Gamma Natural en España); Editor Consejo de Seguridad Nuclear. Available online: https://www.csn.es/mapa-de-radiacion-gamma-natural-en-espana-marna (acccessed on 6 August 2019).

(C) 2019 by the authors. Licensee MDPI, Basel, Switzerland. This article is an open access article distributed under the terms and conditions of the Creative Commons Attribution (CC BY) license (http:/ / creativecommons.org/licenses/by/4.0/). 